widespread breeding population. These munias are often sold in pet stores on the island.

It would appear that on Okinawa the resident Rufous Turtle Dove, Brown-eared Bulbul, Japanese White-eye, Fan-tailed Warbler, and Scaley-breasted Munia are multiple-brooded. Many resident species start their breeding cycle early in the year while two migratory species, the Narcissus Flycatcher and the Ruddy Kingfisher Halcyon coromanda, do not arrive and begin singing until April. It was noted that nest building may extend over five weeks for Pacific Swallows. At one colony near Kadena, the building of nests was observed to occur over a four week period with interruptions apparently caused by wet, cold weather. Barn Swallows Hirundo rustica build a very similar nest and in Michigan, U.S.A., at $44^{\circ} \mathrm{N}$ latitude, they usually take no more than two weeks to build a nest, including interruptions by weather (pers. obs.). The O.S.J. Check-list (1974) does not list the Indian Pratincole or Scaley-breasted Munia as nesting on Okinawa. Also, knowledgeable local bird watchers know of no previous nest records, so the records presented here may be the first for the island.

Literature Cited: OSJ (ORNIthological SociETY of JAPAN), 1974. Check-list of Japanese Birds. 5th ed. Tokyo, Gakken. WALKeR, E. H. 1954. Important Trees of the Ryukyu Islands. Naha, The United States Civil Administration of the Ryukyu Islands.

(Author's address: PCS 1 Box 27481, APO 96230, Kadena Air Base, Okinawa)

沖縄における鳥類の繁殖観察＼cjkstart沖縄本島に拊息類の繁殖については比較的記録が少ない。筆 者は，1980 年 9 月から 1984 年 7 月までの間に見聞した 22 種の繁殖について述べた. そのうち、ッ バメチドリ Glareola maldivarum とアミハラ Lonchura punctulata は新しい繁殖記録である。—D. W. McWhiRTER (在日アメリカ空軍嘉手納基地)

\title{
Notes on the Okinawa Rail Rallus okinawae: Observations at night and at dawn
}

\author{
Mark BRAZIL
}

Recent studies of the Okinawa Rail Rallus okinawae have concentrated on the behaviour of birds visiting forest pools in the late afternoon, and on their vocalizations (IKENAGA, 1983; BRAZIL, 1984a $\& b$ ), and since this is a shy, retiring and difficult to observe species, few details of other aspects of its behaviour or ecology have yet been described. Although popular accounts and photographs have appeared in Japanese in various non-scientific publications, even now, four years after its discovery, almost nothing is known of the bird outside Japan.

During studies in Okinawa in December 1982, and July and December 1983 (BrazIL, 1984a), rails were heard early in the morning, just before sunrise, and in the late afternoon just betore sunset, but were only seen around dusk, supporting popular accounts that the bird is either chiefly diurnal or partially crepuscular. During a study of the distribution of the species in the northern third of Okinawa (known locally as Yanbaru) and of its vocal responses to playback of various calls, in September 1984 (BRAZIL, 1984b, in prep. a \& b), most records were at night, and of calling birds. In calm, late evening and early morning air their calls carry further than at other times of day when there is a high background noise of cicadas. The vocal activity of this bird may well be adapted so as not to coincide with the main period when cicadas are active.

On two occasions birds were seen at night and before dawn and since there are no other accounts in English of the birds behaviour at these time they are reported here. On 29 September 1984, a single bird was heard calling at 00:28 close to the main road along the east coast of Okinawa, approximately $8 \mathrm{~km}$ north of Arakawa dam. A search of the vicinity revealed the bird at 00:36. From details of its plumage it was thought that it may have been an immature bird, perhaps a bird of the year, or a subadult. Its entire head seemed dull grey-brown rather than having black sides and a brown crown 
(see YAMASHINA \& MANO, 1981), it had a whitish patch encircling the eye and a very poorly defined white eye-stripe leading back from the eye, the bill lacked the normal bright scarlet base with a pale ivory tip and instead was a much paler organge-red fading to a yellowish tip, and the black and white barring on the flanks appeared neither as extensive nor as clearly defined as in adults observed on previous occasions, an appearance seemingly intermediate between thsoe of the adult (plates 1 \& 2) and the juvenile (plate 3) illustrated in Yamashina \& MANo (1981). When first observed it was motionless, standing on a dead branch protruding above tall grasses, completely in the open above a ditch. It was roosting on its right leg only, its left leg was tucked up under its belly and its head was tucked into its body feathers on the left side. At 00:37 it looked around nervously, then at 00: 39 it stretched its left wing and left leg simultaneously, then stood on both legs. Except while stretching and looking round its general attitude was hunched with the neck drawn in, making it appear very rounded. It was still in the same position when I left at 00: 45 having been apparently undisturbed by my use of a flashlight. Published photographs of adults roosting in trees, show then on branches sheltered under the canopy of evergreen broadleaf forest (see Anima, (138): 72-79, 1984) this may well be the more typical roosting site, whereas the bird observed was apparently both immature and unmated (pairs usually duet, BRAZIL, in prep. b) and its roosting site may be atypical.

Later the same moring, at 06:14, a pair were heard duetting in primary broadleaf evergreen forest near a forestry track high in the hills of northern Yanbaru. After searching the area a single adult bird was seen, at 06: 20, walking up a sloping tree-trunk about $3 \mathrm{~m}$ above the ground. It continued walking until the trunk thinned to about $3-4 \mathrm{~cm}$ in diameter, then it crouched slightly and leaned forwards until its head was visible below its perch, it returned briefly to a more horizontal posture then leaned forward again, this time continuing until it finally stepped off the branch, fluttering its wings very rapidly as it did so. The wings made a very audible whirring sound, but although they may have slowed its descent a little they did not prevent it from falling vertically into the vegetation below, from where it ran off into the forest.

Very few observations of Okinawa Rails have been reported and during a week long study of the species only four birds were seen, thus it was extremely lucky to see two different birds during the same night. Although chicks and juveniles have been described and photographed (YAMASHINA \& MANo, 1981), I am unable to find any previous references to immature/sub-adult plumage. These observations also confirm that Okinawa Rails, at least on occasions, roost in trees, (IKENAGA, pers. comm., has also seen a single bird in a tree at night) and lends further support to the generally held belief that the species is essentially flightless.

Its flightless nature, its tameness at its roosts and the fact that it nests on the ground all make it extremely vulnerable to predation. In the past natural predators may have only included the various snakes which inhabit the region and possibly crows both of which might take eggs and young. Several species of birds of prey winter in the area and they may be capable of taking adults, however feral cats are now widespread in the forests of northern Okinawa, with sightings made every night in rail habitat during the September 1984 study, and a species of mongoose has been introduced and is spreading steadily northwards up the island. The addition of two mammalian predators seems almost certain to adversely affect this species.

Literature Cited. BRAZIL, M. A., 1984a. Observations on the behaviour and vocalizations of the Okinawa Rail Rallus okinawae. J. Coll. Dairying, 10: 437-449. BrazIL, M. A., 1984b. One on tape is worth three in the bush. BBC Wildlife, 2: 574-575. BRAZIL, M. A., in prep. a. The distribution and abundance of Okinawa Rails in Yanbaru, northern Okinawa Island. BRAZIL, M. A., in prep. b. Vocal responses of the Okinawa Rail. IkenAGA, H., 1983. Appearance time and behaviour of the Okinawa Rail Rallus okinawae at a water site in the late afternoon. (In Japanese with English summary). Strix, 2: 1-11. Yamashina, Y., \& T. Mano, 1981. A new species of rail from Okinawa Island. J. Yamashina Inst. Orn., 13: 1-6.

(Author's address: Rakuno Gakuen Daigaku, 582 Nishi-Nopporo, Ebetsu-shi, Hokkaido 069-01)

夜間および夜明けのヤンバルクイナの観察１984 年 9 月, 沖縄本島北部におけるヤンバルクイナ Rallus okinawae の分布調查中に, 夜間拈よび夜明けの本種の行動を観察した。この鳥の鳴き声は, セミ類（土着の種が多数あるが，一般に鳴き声が大きく，大変うるさい）の鳴き声がとだえる夕方拉 
そくおよび早朝にもっとも多く聞かれた。とくに，つがいによるデニエットおよび数つがいによるコ ーラスは，夕方おそくに聞くことが多かった。 また夜半に，塒で休息中の幼鳥 1 羽と木の上にとまっ ていた成鳥羽を観察し, 幼鳥の羽色について記載した。— Mark BRAZIL (酪農学園大学).

$$
\text { ナミエヤマガラの一腹 卵数 }
$$

樋口広芳・長谷川雅美

ナミエヤマガラ Parus varius namiyei は, 伊豆諸島の利島, 新島, 神津島に生息するヤマガラの 1 悪種である. この鳥の生態についてはこれまでほとんど報告がなく, 繁殖生態はまったく調べられて いない，筆者らは神津島で巣箱を架設し，一腹卵数について調査したので，ここにその結果を報告す る.

巣箱は 1975-1978 年に島の北部地域に毎年 20 個, 1984 年に北部と南部に合わせて 52 個架設し た. 架設地域は主に照葉樹林の林縁であったが，一部の巣箱はスギの造林地や二次林内に架設した. 巣箱の巡回は, 毎年 4 月中旬から 5 月中旬にかけて 3, 4 回行なった. これらの調査により, 初卵日 やふ心化日などは正確に知ることはできなかったが，一腹卵数については確かめることができた，巣箱 を利用している種がヤマガラであるといらことは，抱卵中または育雛中の親鳥を見ることによって確 認した.

この調查期間中に架設した巣箱の数は延べ 132 個になるが，そのらちヤマガラが繁殖に利用したの

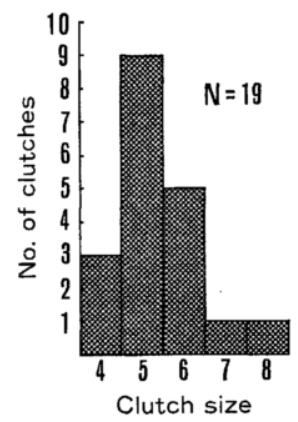

Fig. 1. The frequency distribution of clutch size of Varied Tits Parus varius on Kohzu-shima island.

Table 1. Comparison of clutch asizes between three subspecies of Varied Tits $P$. varius. Statistical tests are shown below.

\begin{tabular}{|c|c|c|c|c|c|}
\hline \multirow{2}{*}{ Subspecies } & \multirow{2}{*}{\multicolumn{2}{|c|}{ Study area }} & \multirow{2}{*}{$N$} & \multicolumn{2}{|r|}{ Clutch size } \\
\hline & & & & Range & $\operatorname{Mean}_{ \pm}$S.D. \\
\hline P. v. varius & Izu & 1., mainland & 85 & $3-8$ & $6.26 \pm 0.82^{1}$ \\
\hline$P . v$. namiyei & Kol & -shima, Izu Is. & 19 & $4-8$ & $5.37 \pm 1.01$ \\
\hline \multirow[t]{2}{*}{ P. v. owstoni } & Miy & -jima Izu Is. & 77 & $3-6$ & $3.95 \pm 0.76^{1}$ \\
\hline & & Mann-Whitney $U$ & $z$ & & $\begin{array}{l}\text { Significance level } \\
\text { (one-tailed) }\end{array}$ \\
\hline \multirow{2}{*}{\multicolumn{2}{|c|}{$\begin{array}{l}P . v . \text { varius vs. } P . v . \text { namiyei } \\
P . v . \text { namiyei vs. } P . v . \text { owstoni }\end{array}$}} & 369 & -3.928 & & $P<0.001$ \\
\hline & & 185.5 & -5.411 & & $P<0.001$ \\
\hline
\end{tabular}

\footnotetext{
${ }^{1}$ Calculated from HiguchI (1981).
} 